\title{
Mahalleye Dönüşen Köylerin Muhtarlarının Hizmetlerde Etkinlik ve Verimliliğe iliş̧kin Algısı: Muğla Deneyimi ${ }^{1}$
}

\begin{abstract}
Mahalleye Dönüşen Köylerin Muhtarlarının Hizmetlerde Etkinlik ve Verimliliğe ilişkin Algısı: Muğla Deneyimi

Öz

Türkiye'de 2014 yılı Nisan ayında yürürlüğe giren ve temel gerekçelerinden birisi yerel yönetimlerce sunulan hizmetlerde etkinlik ve verimlilik sağlanması olan 6360 Sayılı Kanun ile yerel yönetim yapısında büyük değişiklikler getirilmiştir. Büyükşehir belediyelerinin sınırı il mülki sınırlarına genişletilmiştir. Hizmet ölçeği büyütülerek büyükşehir belediyelerin mali gücü arttırılmıştır. Yine, büyükşehir belediyelerinin bulunduğu illerde belde belediyeleri kaldırılmış ve köyler beldelerle birlikte ilçeye bağlı mahallelere dönüştürülmüştür. Bu çalışmada kanunun hedeflerinin ne ölçüde gerçekleştiği, örneklem olarak alınan Muğla ilinde öncesi ve sonrası görev yapan muhtarlar ile görüşülerek anket tekniğiyle ortaya konulmaya çalışılmıştır. Muhtarlardan alınan bulgular, kanunun temel amaçlarından biri olan etkinlik ve verimlilik bağlamında değerlendirilmiştir. Değerlendirme sonucu yerel hizmet sunulan ölçeğin önemini ortaya çıkmış, mahalleye dönüşen köylerde farklı hizmet beklentileri olduğu görülmüştür.
\end{abstract}

Anahtar Kelimeler: 6360 Sayılı Kanun, Etkinlik-Verimlilik, Köy, Mahalle, Muhtarlar
Views of the Mukhtars on Efficiency and Productivity in Local Services after Transforming Neighborhood: Muğla Experience

Abstract

With the Law No. 6360, which began to rule in April 2014, aiming ensuring efficiency and efficiency in the services provided by local governments, major changes were introduced in the local government structure in Turkey. The service area of metropolitan municipalities expanded to provincial boundaries. The scale of local services and the financial power of metropolitan municipalities were increased. The towns and villages have been transformed into neighborhoods of districts in the metropolitan municipalities. This study aims to examine the extent to which the law, in views of mukhtars, being as a mukhtar before and after the law, by a survey and loose structured interview. The findings were evaluated in terms of efficiency and efficiency in local services. The result shows the importance of the scale of the local service has emerged and there are different service expectations in the villages that have been transformed into the neighborhoods.

Keywords: Law no.6360, Efficiency-Productivity, Village, Neighborhood, Muhktars

\section{Giriş}

2012 yılında çıkarılan 6360 Sayılı Kanun ile Türkiye'de büyükşehir belediyesi sayısı otuza çıkarılmıştır. Sınırları il sınırlarına kadar genişletilen yeni büyükşehir belediyeleri oluşturulurken, il Özel İdareleri ve belde belediyelerinin yanı sıra köylerin tüzel kişilikleri kaldırılmıştır. Köyler aynı adla mahalleye, beldeler de beldenin adıyla tek mahalle olarak ilçe belediyesine bağı mahalleye dönüştürülmüştür. Türk yerel yönetim tarihinde ve mevcut idari yapılanmasında farklı bir konumu bulunan köylerin, 6360 Sayılı Kanun ile büyükşehir belediyesi kurulan illerde mahalleye dönüşmesi sonucu birçok açıdan yeni bir sürece girilmiştir. 5393 sayılı Belediye Kanununun 3. maddesinde mahalle "belediye sınırları içinde, ihtiyaç ve öncelikleri benzer özellikler gösteren ve sakinleri arasında komşuluk ilişkisi bulunan idarî birim" olarak tanımlanmıştır. Yıllarca

\footnotetext{
${ }^{1}$ Bu çalışma Marmara Üniversitesi Sosyal Bilimler Enstitüsü Yerel Yönetimler Anabilim Dalı’nda Prof. Dr. Yüksel Demirkaya danışmanlığında, Mesut Koç tarafından “6360 Sayılı Kanunun Mahalleye Dönüşen Köylerde Muhtarlığa Etkisi: Muğla Deneyimi" ismiyle tamamlanarak 28.06.2018 tarihinde savunulan doktora tezinden türetilmiştir. 4. Kamu Yönetimi Sempozyumunda özeti sunulan bildirinin genişletilmiş halidir.

2 Dr. Öğr. Üyesi, Burdur Mehmet Akif Ersoy Üniversitesi, Gölhisar Uygulamalı Bilimler Yüksekokulu, mesutkoc@gmail.com, yazar ORCID bilgisi: https://orcid.org/0000-0002-0231-747X.
} 
442 Sayılı Köy Kanununa göre idare edilmekte olan yeni mahallelerde yerel hizmetleri sağlamakla görevli kurumların farklılaşması sonucu etkinlik ve verimlilik başta olmak üzere önemli değişiklikler olması kaçınılmazdır. 6360 Sayılı Kanunun temel gerekçelerinden birisi yerel yönetimlerce sunulan hizmetlerde etkinlik ve verimlilik sağlanması olmuştur. Bu değişikliklerin geçen süre içerisinde sahaya yansımasını ve hedeflerinin ne ölçüde gerçekleştiğini ortaya koymak bu düzenlemenin bundan sonraki seyri içinde belirleyici olacaktır. Diğer taraftan 6360 Sayılı Kanun öncesi köy muhtarı olarak görev yapan ve yasanın uygulanmaya başlaması ile birlikte, herhangi bir siyasi parti şemsiyesi altında olmadan mahalleyi temsil etmek üzere tekrar seçilen mahalle muhtarları köyden mahalleye dönüşümün canlı tanıklarıdır. Köy iken sahip oldukları tüzel kişilikleri kaldırılmış ve muhatap oldukları yerel hizmetleri sağlamakla görevli büyükşehir belediyesi ve ilçe belediyesi olmak üzere iki belediye çıkmıştır. Muhtarların 2014 yılı ile birlikte mahallelerinde başlayan yeni süreçte, 4 yıllık deneyimleri oluşmuştur. Bu deneyimin sahada bulunan aktörlerin katkılarıyla literatüre kazandırılması karar vericilere ışık tutacaktır.

6360 Sayılı Kanun ile birlikte büyükşehir olan 14 ilden birisi Muğla'dır. Sınırlarının bir kısmı Ege bölgesi bir kısmı Akdeniz bölgesinde bulunan Muğla, 1479 km’yi bulan deniz kıyısına sahip coğrafi yapısının yanı sıra sahip olduğu kırsal alanlar, geçim kaynakları ve birbirinden çok farklı özelliklere sahip ilçeleriyle araştırmanın amacına için uygun illerden birisidir. Çalışma kapsamında; 2009 yılı yerel seçimleri ile birlikte köy muhtarı olarak seçilen ve 2014 yılından itibaren ilçe belediye sınırları içerisinde mahalleye dönüşen yerlerde tekrar seçilip mahalle muhtarı olarak halen göreve devam eden; hem merkezi yönetimin temsilcisi hem de mahallesinin yerel nitelikli ihtiyaçlarını karşılamaya çalışan mahalle muhtarlarının 4 yıllık deneyim sonunda hizmetlerde etkinlik ve verimliliğe ilişkin algısı araştırılmıştır. Çalışmada; öncelikle kavramsal çerçeveye yer verilmiştir. Etkinlik ve verimlilik, yerel hizmetlerde etkinlik ve verimlilik ve 6360 Sayılı Kanunda etkinlik ve verimliliğe ilişkin değerlendirmeler ve güncel araştırma sonuçları sunulmuştur. Yerel yönetim birimi olan köy ile birlikte mahalle ve muhtarlıklarına değinilerek 6360 Sayılı Kanun ile birlikte gelen değişiklikler irdelenmiştir. Araştırma sonucunda elde edilen bulgular analizi sonuç ve değerlendirme bölümüyle bitirilmiştir.

\section{Kavramsal Çerçeve}

Dünya kamu yönetimleri, gelenekselden yeni kamu yönetimi anlayışına evrilirken öne sürülen temel argümanların başında etkinlik ve verimlilik gelmektedir. Burada kamu örgütlerinin hizmet sunmadaki performans ölçümünde etkinlik ve verimlilik öne çıkmaktadır. Nitekim kamu hizmet sunumunda etkinlik sağlama reformlarla ulaşılmak istenen temel hedeflerden biri haline gelmekte ve dolayısıyla kamu yönetiminde etkinlik ve verimlilik sağlama düşüncesi hem geleneksel yönetim düşünürlerinde hem yeni kamu işletmeciliği reformlarında kendine önemli yer bulmaktadır (Al, 2002: 253).

Yerel yönetimlerin demokratiklik boyutunun yanında yönetimin etkinliği ve verimliliği önemli bir boyuttur. Demokratik işleyişte halkın sadece alınan kararlardan haberdar olması yeterli değildir. Burada önemli olan nokta, halkın bu kararların kendi yararına olduğu noktasında ikna da olmasıdır. Bunun için de yerel yönetimler ya da yerel karar alıcılar ile halkın işbirliği yapması, halkın karar alma sürecine, programların hazırlanmasına katılımı, görüşlerin alınması, bilgilendirilmesi, yani yönetsel işleyişe aktif bir şekilde katılımı gerekmektedir. Ayrıca her kamu kuruluşu gibi yerel yönetimlerin izlediği politikaların halka açıklanması, halkın belediye hizmetlerine karşı olumlu bir tutum sergilemesini de sağlayıcı bir etki oluşturmaktadır (Öner, 2006: 19). Yönetime katılımın ideal boyutta gerçekleştiği oranda hizmetlerde etkinlik ve verimlilik de artacaktır. 
Kâr amacı gütmeyen çeşitli kamu ve özel örgütlerde verimliliğin tam olarak ölçülememesi, verimliliği bir ölçüt olarak alan ve verimlilikten daha geniş bir kavram olan etkinlik kavramının ortaya atılmasına neden olmuştur (Yıldırım, 1984: 44). Kamu yönetiminde "verimlilik" kavramından daha çok "etkinlik" terimi tercih edilir. Çoğu kamu hizmetinin (güvenlik ve yargı gibi) değerinin para ile ölçülememesi, kamu hizmetlerinin çok yönlü amaçları, kullanılan kaynakların nitelikleri gibi faktörler, kamu yönetiminde, özel sektörde olduğu gibi girdi-çıktıya bakarak kantitatif bir hesaplama yapmayı zorlaştırmaktadır (Eryılmaz, 2012: 172). Son dönemde ise etkinlik ve verimlilik kavramlarının birlikte kullanımına sıkça rastlanmakta ve bu kavramlar, 6360 Sayılı Kanun ile birlikte ölçek ve optimal kent büyüklükleri gibi kavramlarla ilişkilendirilmektedir.

\subsection{Kavramsal Açıdan Etkinlik}

Etkinlik kavramı üzerinde düşünürler tam bir fikir birliği içinde değildir. Etzioni, Barnard, Hall ve Price'a göre etkinlik, kamunun amaçlarını gerçekleştirme derecesidir. Katz ve Kahn ise etkinliği, örgütün çıktılarının mümkün olan bütün yollardan (ekonomik, teknolojik, siyasal, vb.) en yüksek düzeyde çıkarılması olarak tanımlamaktadır. Schein'a göre örgütsel etkinlik, herhangi bir sistemin, yerine getirdiği özel işleve bakılmaksızın yaşama, çevreye uyum, kendini devam ettirme ve büyüme kabiliyet ve kapasitesidir. Mott'a göre bir örgütün, üretim ve çevreye uyumu gerçekleştirmek üzere güç merkezlerini harekete geçirme yeteneğidir. Chris Argyris'e göre ise, amaçların başarılmasında denge ya da optimalliktir (Ceritli, 2002: 10). Drucker'a göre verimlilik işlerin doğru yapılmasıyla ilgilidir; etkinlik ise doğru işlerin yapılmasını ifade etmektedir. Dolayısıyla verimlilik girdiler ve çıktılarla ilgilenirken, etkinlik çıktılar, sonuçlar ve bunların etkileriyle ilgilidir (Drucker, 1994: 44).

Yerel yönetimlerin dayandığı değerler arasında özgürlük ve katılım ile birlikte etkinliğin de olduğuna dikkat çeken Keleş, "Yerel yönetimlerin kimi kamu hizmetlerini halka etkin bir biçimde sunmaları da varlık nedenleri arasındadır." demektedir (Keleş, 2012: 51-52). Tortop ise; örgütlerin tanımlanmış amaçlarına etkinlik ve stratejik hedeflerine ulaşmak amacıyla gerçekleştirdikleri faaliyetleri sonucunda bu amaç ve hedeflere ulaşma derecesini belirleyen bir performans boyutu olarak ifade etmektedir (Tortop ve diğerleri, 2007: 285).

Kentlerin ekonomik sürdürülebilirliğinde, kent içerisinde ve çevresinde yürütülen mal ve hizmetlerde etkinlik ve verimliliğin gerçekleştirilmesi dikkatlerden uzak tutulmaması gereken bir öneme sahiptir. Bununla beraber etkinlik ve verimlilik kavramları, çoğulcu, katılımcı, geçişken ve insan merkezli demokratik yerel yönetim bağlamında ele alındığında zaman bir anlam ifade etmektedir. Etkili hizmet sunumu, daha iyi ve daha yaygın hizmet dağıtımı demektir. Verimlilik ise hizmetlerin en düşük maliyetle üretilmesini ifade etmektedir. Bu bağlamda yerel yönetimler, hem etkili hem de verimli bir şekilde hizmet üretme ve dağıtma sorumluluğunu taşımaktadırlar (Duben ve Emrealp, 1993: 17).

Öztürk'te kamu hizmetlerinde etkinlik için desantralizasyona (yerinden yönetimleştirme) işaret etmekte ve kamu hizmetlerinde etkinlik bakımında hangi hizmetlerin hangi kurumlarca yapılacağının üzerinde durulmasının faydalı olacağını söylemekte ve hizmetlerin özelliklerine göre hareket edilerek desantralizasyon yapılması gerektiğine dikkat çekmektedir (Öztürk, 2004: 21). 
Öztürk, demokratik ve etkin bir yönetim kurulabilmesi için yapılacak reformlarda dikkat edilmesi gereken hususları aşağıdaki şekilde sıralamaktadır:

1. Genel olarak kamu sektörünün verimliliği önündeki çevre, örgüt ve personelden kaynaklanan engelleri aşmak gerekir. Verimliliğin kamu yönetimi bakımından öncelikli bir konumda olması gerektiği bilinci yaygınlaştırılmalıdır.

2. Devletin hantal yapıdan kurtarılması için bazı üretim ve hizmet alanlarından çekilmesi gerekir. Devletin ekonomik ve sosyal hayattaki rolünün azaltılması ve küçülmesi, kamu kurumlan arasındaki koordinasyon problemini sürdürülebilir seviyeye indireceği için etkinliğe katkı sağlayabilir.

3. Belirli amaçları gerçekleştirmek için oluşturulan kurumlar bu amaçlar gerçekleştiğinde veya gerçekleşmeleri imkânsız olduğu zamanlarda kapatılmalıdırlar. Fonksiyonelliği kalmamış kuruluşlarım vatandaşın sırtına yük olmasına engel olunmalıdır. Görevlerini tamamlayan kurumlar kapatılmalı, ihtiyaç halinde yeni kurumlar oluşturulmalıdır.

4. Kamu yönetiminin personel sistemi ve kurumsal yapısı radikal bir şekilde yeniden gözden geçirilmeli ve insan kaynakları yönetimime geçilmelidir. Liyakat ilkesinin uygulanmasından kesinlikle taviz verilmemeli, siyasal atamalar sadece en üst görevlerle sınırlandırılmalıdır.

5. Karar alımı süreçlerine katılım sağlanmalıdır. Karar alımı ve uygulamasına halkın katılımı yönetimin etkinliğini ve etkililiğini artırıcı bir unsur olarak katkı sağlar.

6. Bilgisayar teknolojisi ve internetten daha çok yararlanmanın altyapısı oluşturulmalıdır. Edevlet uygulamaları ve kamu kurumlan arasındaki koordinasyonun sağlanması ve bilgi paylaşımı yoluyla hem şeffaf devlet gerçekleştirilebilir hem de halkın karar alımı süreçlerine aktif katılımı sağlanabilir.

7. Kamunun yaptığı diğer işlerden dolayı ayrılacak tahsisatın kimlere ve ne kadar dağıtılacağının belirlenmesinde fayda-maliyet kriterleri göz önünde tutulmalıdır. Böylece hem kamu kaynaklarının verimli alanlarda kullanımı sağlanacak hem de devletin vatandaş yararına etkinliği gözetmesine imkân tanınacaktır.

Kamu hizmetlerinde etkinlik anlayışında dikkat edilmesi gereken bir başka önemli nokta ise kamu hizmetlerine ihtiyaç var ise bu ihtiyacın ne miktarda olacağının etkinlik arayışı gereği sorulması ve cevap aranması gerekir (Bilgin, 2004: 37).

Kesgin, etkinlikle demokrasinin birbiriyle bağlantısından hareketle, dünyanın geldiği noktada etkinlik ve demokrasi kavramlarının yönetimler açısından olmazsa olmaz bir ilke olduğu konusunda bütün tarafların mutabakata vardığını söylemektedir. "Yerel yönetimlerden günümüz dünyasında beklenilen, dünyanın geldiği noktadan hareketle demokrasiyi ve etkinliği uyumlulaştırmaları, özellikle demokratik katılımdan ve halk denetiminden taviz vermeden verimli/etkin bir yönetim ortaya koymalarıdır. Bu zor olmakla beraber, bunun zorunluluk arz ettiği de görülmelidir. Yaşadığımız dünyada kamu yönetimlerinin dolayısıyla yerel yönetimlerin etkin, başarılı ve verimli olması isteniyorsa, kamu yönetimlerinin demokrasiyle bağlantısını güçlü kılmak durumundayız. Ayrıca demokratik katılımın ve vatandaş memnuniyetinin kamu yönetimlerini destekleyen ve onların başarısını kamçılayan gerçekler olduğu da unutulmamalıdır. Etkinlik ile demokratikliği uyumlaştırmak kamu yönetimlerinin misyonuna daha uygun düşmektedir" demektedir (Kesgin, 2015: 173). 


\subsection{Kavramsal Açıdan Verimlilik}

Verimlilik, bir mal ve hizmetin üretimi için kullanılan kaynak (girdi) ile elde edilen sonuç (çıktı) arasındaki ilişkiyi tanımlayan bir kavramdır (Eryılmaz, 2012: 172). Belli düzeydeki bir çıktının en az girdi ile elde edilmesi veya belli bir miktar girdi ile en fazla çıktı sağlanmasıdır (Tortop ve diğerleri, 2007: 285). Diğer bir ifadeyle; mevcut kaynaklardan en iyi derecede faydalanabilmeyi anlatır. Bu kaynaklar, ilgili hizmet sunumunda kullanılacak her türlü araç, gereç, insan gücü, bilgi ve beceri olarak sıralanmaktadır (Kuyaksil, 1994: 162). Eryılmaz, verimliliği etkinlik kavramı ile birlikte ilişkilendirerek; "bir ölçüde verimlilik unsurunu da içeren etkinlik kavramı, daha çok bir örgütün amaç ya da amaçlara ulaşma derecesini anlatır. Amaçların doğru belirlenmesi ve bunlara kısa zamanda ulaşılması, etkinlik kavramıyla ifade edilir. Bir itfaiye aracının, yangın ihbarı aldıktan sonra kısa zamanda yangın mahalline ulaşması, yanı̆̆ı kısa sürede söndürmesi, can kaybını önlemesi, verimlilikten daha çok etkinlikle ilgilidir. İtfaiye dairesi, mal ve can kaybını önlemek için çok kaynak (girdi) kullanmış da olabilir. Bun anlamda verimsizdir" diyerek açıklar (Eryılmaz, 2012: 172).

Verimliliğin hizmet ile ilişkisini dair Alkuş, hizmetlerin verimliliğini ölçmenin, soysal değişkenler, kalite ve değerden etkileneceği için zor olduğuna dikkat çeker. "Hizmetin kalitesini bina, malzeme ve personel etkiler. Hizmetin verimliliğinin ölçümünde iki ölçüt kullanılabilir. Bunlardan biri memnuniyet diğeri de etkinliktir. Hizmet üretiminde miktar ölçütlü verimlilik değerlemesi yapılamaz. Hizmetin verildiği bina, makine, malzeme ve personel, müşteri için önem arz eder. Hizmette personelin ve müşterinin memnuniyetine dayanan verimlilik önemlidir. Bir örgütün hizmet verimliliği diğer bir örgütün hizmet verimliliği ile kıyaslanarak (benchmarking) ölçülebilir. Yine bir örgütün hizmet verimliliği, performans ölçümüyle de olabilir" (Alkuş, 2015: 549).

Kamu yönetiminde verimliliğin ölçülmesi ya da somut olarak ifade edilmesi ve verimlilik analizlerinin yapılması özel kesime kıyasla oldukça zordur. Bunda, kamu kesiminde üretilen birçok hizmetin rakamsal maliyetinin ifade edilmesindeki güçlük ve tercih edilme vb. gibi dış unsurlar etkilidir. Verimlilik yalnızca kamu hizmetlerinin niceliksel yönleriyle ölçülebildiği alanlarda etkili olabilirken, etkinlik bütün kamu hizmetleri için geçerlidir (Şahin, 2007: 56).

Kamu kurumlarının verimlilik geliştirme çabalarında özel sektörden daha fazla çaba sarf etmek durumunda olduğuna vurgu yapan Öztürk, buna gerekçe olarak kamu organizasyon ve hizmetlerinin çok sayıda ve birbirinden farklı kişilerce etki altında olmasını gösterir. Bu kişiler kamusal karar verme sürecinde etkili olabilme potansiyeline sahiptirler. Bu kadar geniş çevresi ve çok sayıda müdahale edenin olmasından dolayı kamusal danışma süreci, iyileştirme çabalarını oldukça yavaşlatmaktadır. Ayrıca kamu kurumları devletin çok sayıdaki kurumu ile ilgilenmek ve onlara danışmak durumundadırlar. Bunun yanında belirtmek gerekir ki, kamu kurumlarının yapacakları düzenlemelerde bu düzenlemelere katılan veya katılması gereken çevrelerin istek ve ihtiyaçları genellikle birbiriyle uyuşmaz. Bundan dolayı verimlilik geliştirme çabalarında bu çok yönlülüğü görebilmek gerekir. Başka bir ifadeyle verimlilik geliştirme çabaları bu birbirinden farklı yönleri açıklayabilmelidir (Öztürk, 2004: 2).

\subsection{Yerel Hizmetlerde Etkinlik ve Verimlilik}

Son yıllarda kamu yönetiminin en çok etkilendiği disiplinlerin başında işletme yönetimi gelmektedir. Sanayi devrimi ile birlikte ortaya çıkan/gelişen işletmeler ve bunların yönetimine ilişkin geliştirilen düşünce, yapı, yöntem ve ilkeler, bilgi toplumunda da dinamizmini arttırarak de- 
vam ettirmektedir. Bilindiği gibi sanayi devrimi, bilginin üretim araçlarına uygulanmasıyla ortaya çıkmıştır. 19. Yüzyıla "Sanayi Çağı" damgasını vurmuştur. 20. yüzyılın başında, bilginin örgütlere ve çalışma hayatına uygulanmasıyla "yönetim devrimi" meydana gelmiştir. Yönetim devrimiyle birlikte kamu ve özel sektörde verimlilik ve etkinlik artmıştır. Bu yüzden 20. yüzyıldaki hâkim gelişmeyi anlatmak için, "Verimlilik Çağı" kavramı kullanılmıştır (Eryılmaz, 2012: 93).

Kamu yönetiminde etkinlik ve verimlilik bir bütün anlayış olarak ele alındığında bazı demokratik değerler olarak görülebilecek kavramlarla bir arada da değerlendirilmektedir. Bir hizmetin halka en yakın yerde sunulması, kaliteli hizmet sunumu, hesap verebilirlik bunlar arasındadır (Al, 2002: 255). Özden, bu ilkelerle yerel yönetimlerin kuruluş amacını özdeşleştirerek; "kamu hizmetlerini daha etkin sunabilmek için yönetim bazı kurumlara ve coğrafi birimlere hizmet sunumunda özerklik vererek kamu hizmetlerinin verimliliğini ve hizmet alan kitlenin memnuniyetini arttırmak istemiştir. Hizmet yönünden yerinden yönetim kurumları ile yer yönünden yönetim kurumları, yerel yönetimler bu amaçla ortaya çıkmış birimlerdir. Bu noktada daha iyi yönetim, yönetişim ile demokrasinin birlikte ortaya çıktığı görülmektedir. Bir yandan yönetişim ile kamu hizmetlerinin kalitesi arttırılırken bir yandan da bir açıdan halkın sesine kulak verilmesi olarak yorumlanabilecek demokrasi yerel yönetimlerde kendini göstermektedir" demektedir (Özden, 2014: 10). Özetle denilebilir ki; yerel yönetimlerin kuruluşu, özerklik, demokratiklik ve etkinlik ilkelerine dayanmaktadır (Bulut, 1999: 13-17).

Etkinlik ilkesi, yerel yönetimlerin verimliliği ve ölçek büyüklüğü tartışmalarını beraberinde getirmiştir. Özellikle, son dönemde yerel yönetimlerle ilgili yapılan yasal düzenlemelerin gerekçelerinde bu tartışmalara vurgu yapılmaktadır. Türk yerel yönetim tarihinin 'etkinlik, verimlilik ve ölçek' arayışları içerisinde geçtiğini söylemek mümkündür (Kaypak ve Kara, 2016: 278).

Türkiye'de etkinlik ve verimlilik kavramlarının mevzuata girişi yeni kamu yönetimi anlayışı ile birlikte olmuştur. 2000'li yıllardan itibaren yasalarda ve yönetmeliklerde; stratejik plan, performans programı, vizyon, misyon, saydamlık, hesap verebilirlik, katılımcılık, öngörülebilirlik, etik, hizmette yerellik, tutumluluk, verimlilik, etkinlik, özelleştirme, halkın memnuniyeti, hizmet standartları vb. geçmeye başlamıştır (Eryılmaz, 2012: 102).

Hizmetlerde etkinlik ve verimliliğin sağlanmasında temel koşul, hizmetlerin halka en yakın birimlerce yerine getirilmesidir. Burada halka en yakın yönetim kimi zaman merkezi idare olurken kimi zamanda belediyeler olmaktadır. Bu ayrım, hizmetin halka dağılım ölçütünden kaynaklanır. Vurgulayabileceğimiz diğer bir nokta da, hizmete en yakın yönetimin halka da en yakın yönetim olduğudur. Bu anlayışın yerleşmesi aynı zamanda yerel demokrasinin de bir gereği olarak karşımıza çıkmaktadır (Negiz, 2007: 46).

Kamu yönetimi reformları ile daha demokratik, daha etkin, daha verimli, daha şeffaf ve daha hesap verebilir bir yerel yönetim sisteminin oluşturulması hedeflenmiştir. Bu çerçevede belediyelere yönelik yeni yetki ve kaynak transferi yapılmış ve beraberinde yeni bir örgütlenme sağlanması zorunlu kılınmıştır. Bu örgütlenme modelinin özündeki stratejik yönetim ile hedeflenen ise kurumsal performansı yönetilebilir kılmaktır. Haliyle, performans yönetimi ilgili alanda objektif kriterleri belirlemeyi, sistemi kurmayı, ölçmeyi, denetlemeyi ve ödüllendirmeyi gerektirir. Türkiye'de performans ölçümü ve yönetimi gibi kavramlar, kamu yönetiminde yönetilebilinir performans sisteminin geliştirilmesi adına yapılan son on yıllık düzenlemelerle sık sık gündeme gelmeye başlamıştır. Bu alandaki yasal düzenlemelerin öncüsü niteliğinde olan 5018 Sayılı Kamu Mali Yönetimi ve Kontrol Kanunu ile kamu yönetiminde performans odaklı bir yönetsel sistemin hâkim kılınması hedeflenmiştir (Demirkaya, 2016: 28). Bu kanunda kamunun yaptığı harcamaların hedef, amaç, performansla ilişkilendirilmesi yanında, harcama disiplini oluşturma da en 
önemli amaçlardan birisi olarak ortaya konulmuş-tur. Bu ve benzeri yasalarla etkin ve verimli bir kaynak kullanımı ve yönetim anlayışı sergilenmesi hedeflenmiştir (Kesgin, 2015: 163).

Aynı şekilde 5393 Sayılı Belediye Kanunu, 5216 Sayılı Büyükşehir Belediyesi Kanunu gibi yasal düzenlemeler ile 5018 sayılı kanunun düzenlemelerinin ruhuna uygun olarak kurumsal performansın ölçülmesi, denetlenmesi ve raporlanması gibi uygulamalar ile performans odaklı yönetsel bir sistemin kurulması vurgulanmıştır (Demirkaya, 2016: 28). Nitekim bu durum; 5018 Sayılı Kanunun 1. maddesinde; "kalkınma planları ve programlarda yer alan politika ve hedefler doğrultusunda kamu kaynaklarının etkili, ekonomik ve verimli bir şekilde elde edilmesi ve kullanılmasını, hesap verebilirliği ve malî saydamlığı sağlamak üzere, kamu malî yönetiminin yapısını ve işleyişini, kamu bütçelerinin hazırlanmasını, uygulanmasını, tüm malî işlemlerin muhasebeleştirilmesini, raporlanmasını ve malî kontrolü düzenlemektir" ifadesi ile amaç olarak yer almış, 2. maddesinde de "bu kanun, merkezi yönetim kapsamındaki kamu idareleri, sosyal güvenlik kurumları ve mahalî̀ idarelerden oluşan genel yönetim kapsamındaki kamu idarelerinin malî yönetim ve kontrolünü kapsar" ifadesi ile yerel yönetimleri de içine almıştır.

5393 Sayılı Sayılı Belediye Kanunu, 5216 Sayılı Büyükşehir Belediyesi Kanunu ve 5302 Sayılı il Özel İdaresi Kanunu ise 5018 Sayılı Kanundan daha sonra düzenlenmiş ancak bu kanunda öngörülen ilkelere uygun olarak belediyelerde ve il özel idarelerinde performans yönetiminin süreç ve sorumluluklarını tayin etmişlerdir (Demirkaya, 2016: 29).

\subsection{Sayılı Kanunda Etkinlik ve Verimlilik}

2012 yılında çıkarılan ve yerel yönetim yapısında büyük değiş̧iklikler getiren 6360 Sayılı Kanunun temel gerekçelerinden birisi hizmetlerde etkinlik ve verimlilik sağlanması olmuştur. Kanunun temel gerekçesinde; 2004 yılında çıkarılan 5216 Sayılı Büyükşehir Belediyesi Kanununa vurgu yapılarak, "2004 yılında büyükşehir belediyesi yönetiminin hukuki statülerinin düzenlenmesi ve buralardaki hizmetlerin planlı, programlı, etkin, verimli ve uyum içinde yürütülmesi için 5216 Sayılı Büyükşehir Belediyesi Kanunu çıkarılmış olup bu kanun ile aynı zamanda İstanbul ve Kocaeli illerinde büyükşehir belediye sınırları il sınırı olarak kabul edilmiştir" denilmiş ve buradan hareketle yeni büyükşehirler içinde aynı modelin öngörüldüğü belirtilerek; "5216 Sayılı Kanunun yürürlüğe girişinden bu güne kadar İstanbul ve Kocaeli illerinde uygulanan il sınırında büyükşehir belediye modelinin imar, planlama, ulaşım, itfaiye gibi geniş çerçevede eşgüdüm ve bütünlük içerisinde yürütülmesi gereken mahalli müşterek nitelikteki kamu hizmetlerinin sunumunda etkinlik sağladığı görülmüştür" denilmiştir.

6360 Sayılı Kanunun gerekçesinde; "büyükşehir alanında sunulan hizmetlerin tek merkezden yürütülmesi ile ortaya çıkan ölçek ekonomileri sayesinde hizmetlerde etkinlik, koordinasyon ve kalite yükselecek, daha az kaynak ile daha çok ve daha kaliteli hizmet sunulması mümkün hale gelebilecektir" ifadesi ile yeni büyükşehir belediyeleri verimliliğin sağlanacağına dikkat çekilmiştir. Zira aynı vurgu kanun tasarısının sonuç bölümünde de yapılmıştır. "Kanun tasarısıyla mevcut yerel yönetim yapısı ile yerel nitelikteki kamu hizmetlerinin etkin ve verimli bir şekilde sunulması olanağı kalmayan bazı illerde, bu hizmetlerin vatandaşlarımızın artan beklentilerini karşılayabilecek nitelik ve kabiliyetle donatılmış, ideal ölçekte etkin hizmet sunma potansiyeline sahip yerel yönetimlerde sağlanması öngörülmekte ve bu doğrultuda düzenleme yapılmaktadır" denilmiştir. (Kanun Tasarısı için bkz. Kanunlar ve Kararlar Genel Müdürlüğü 8/10/2012 tarih ve 4099 sayılı teklif yazısı) 
Yerel hizmetlerde etkinlik ve verimliliğin sağlanması temel gerekçe olarak sunulan 6360 Sayılı Kanun ile birlikte, büyükşehir belediyelerinin il mülki sınırlarına genişletilmesi ve beraberinde ölçeğin büyümesi sonrası, daha önceden birden fazla merkezden sağlanan hizmetlerin güçlendirilmiş tek merkezden sağlanıp sağlanamayacağı tartışmaların odak noktalarından birisini oluşturmuştur. Kanunun meclisten geçip yürürlüğe girmesi ile birlikte olumlu ve olumsuz birçok görüş öne sürülmüştür. Bu çalışma kapsamında, etkinlik ve verimliliğe ilişkin olarak, 6360 Sayılı Kanun sonrası, büyükşehir belediyelerinin kurulduğu ve hizmete başladığı 2014 yılından sonra alanda yapılan çalışmalara ilişkin değerlendirmeler ön plana çıkarılmaktadır.

2015 yılında yapılan ve 2016 yılında yayınlanan, “6360 Sayılı Yasa ile Köy Yönetiminden Mahalle Yönetimine Geçiş Sonrası Etkin Hizmet Sunumuna İlişkin Muhtarların Görüşü: Silifke Köyleri Örneği" adlı çalışma bu kapsamda yapılmıştır. Mersin ili Silifke ilçesine bağlı, köyden mahalleye dönüşen yerlerin mahallelerinin muhtarları ile görüşme yapılmış ve çalışmanın bir bölümünde muhtarların mahallelerine hizmet getirilmesi konusunda hangi kişi ya da kurumlarla irtibat kurdukları, hizmet için talepte bulunduktan sonra hizmet sunumunun gerçekleşip gerçekleşmediği ve hizmetlerin etkin bir biçimde sunulup sunulmadığına ilişkin görüşleri alınmıştır (Göküş ve Alptürker, 2016: 67). Çalışma sonunda; "muhtarların etkin hizmet sunumuna ilişkin görüşleri değerlendirildiğinde, hizmet talepleri değerlendirilen muhtarların, etkin hizmet sunumu yapıldığı yönünde görüş bildirdiği; hizmet talepleri değerlendirilmeyen muhtarların ise etkin hizmet sunumu yapılmadığı yönünde görüş bildirdiği görülmüştür. Kanaatimizce, muhtarların hizmet etkinliği kavramını yanlış yorumladığı, mahallelerine yapılmış olan herhangi bir hizmetin etkin olduğu anlayışının hâkim olduğu düşünülmektedir. Genel olarak değerlendirildiğinde ise etkin bir hizmet sunumunun söz konusu olmadığı anlaşılmaktadır. Hizmetlerin etkin olarak sunulamamasının nedenleri arasında, mahallelerin kent merkezlerine uzak olması, belediye hizmet alanının büyük olması, yasanın yeni olması ve belediyelerin idari teşkilatlanmasını tam olarak gerçekleştirememiş olması gibi nedenler yer almaktadır" değerlendirmesi yapılmıştır (Göküş ve Alptürker, 2016: 82).

Biricikoğlu ve Duyar tarafından 2015 yılında yayınlanan ve alan araştırması sayılabilecek nitelikte “6360 Sayılı Yasa'nın Genişleyen Büyükşehir Belediyesi Hizmet Sınırının Etkinlik ve Verimliliğe Etkisi Bağlamında Değerlendirmesi: Sakarya Büyükşehir Belediyesi Örneği” isimli çalışmada hizmet sunmakla görevli daire başkanları ile görüşülmüştür. Araştırmada, 6360 Sayılı Kanun ile getirilen büyükşehir belediyesi hizmet sunum alanı değişikliğinin Sakarya ölçeğinde etkin ve verimli hizmet sunumuna etkisi araştırılmıştır. Araştırma sonunda; "yasanın hizmet sunumuna olan etkisine baktığımızda, hizmet sınırlarının il mülki sınırlarına genişlemesinin hizmetin etkin ve verimli sunumunda olumlu yönde bir katkı sağlayacağı ifade edilmiştir. Etkinlik ve verimlilik yanında hizmet sınırının genişlemesinin hizmetlerde kalite, hizmetten yararlanma noktasında da daha adil ve eşitlikçi bir yapı ortaya çıkaracağı vurgulanmıştır. Ancak hizmetlerin etkin ve verimli sunumu noktasında yeni düzenlemenin bir takım sorunları da bulunduğu belirtilmiştir. Bu sorunlar eskiden kalma alışkanlıkların devam ettirilmeye çalışılmasından kaynaklandığı görülmektedir." değerlendirmesi yapılmış ve "6360 sayılı yasa ile büyükşehir hizmet alanının coğrafi alan olarak genişlemesinin diğer bir anlamda hizmet ölçeğinin büyümesinin Sakarya Büyükşehir Belediyesi'nde hizmetlerin etkinliği ve verimliliği açısından olumlu ve olumsuz pratik gözlemleri barındırdığı söylenebilir. Ancak ilçe belediyeleri ile yaşanan sorunlar, mali yapıdan kaynaklı olumsuzluklar var olmakla birlikte 6360 sayılı Yasa'dan önce 10 ilçe ile yürütülen büyükşehrin hizmet sunma tecrübesinin daire başkanlarınca önemli bir avantaj olarak değerlendi- 
rildiği bu nedenle de hizmet ölçeğindeki genişlemenin hizmetlerin etkinlik ve verimliliğini olumsuz bir etkisinin olmayacağı ve yaşanmakta olan mevcut sorunların bir geçiş sürecinden kaynaklı olarak doğal olduğu yönünde genel bir kanı olduğu söylenebilir." denilmiştir (Biricikoğlu ve Duyar, 2015: 390).

Belli ve Aydın tarafından 2016 yılında yayınlanan, “6360 Sayılı Yasa ile Kapatılan Belde Belediyelerinin Hizmette Etkinlik, Verimlilik ve Temsil Sorunsalı Üzerine Bir Alan Araştırması: Önsen Belediyesi Örneği" adlı bir başka alan araştırmasında, kapatılan Kahramanmaraş ili Onikişubat ilçesi Önsen belde belediyesinin katılmadan önce ve kapatıldıktan sonra hizmette etkinlik, verimlilik ve temsile ilişkin ne tür sorunlar yaşadığını belirlemek ve iki dönem arasındaki farkları ortaya konulmaya çalışılmış ve yapılan değerlendirmede; “Alan araştırması kapsamında ortaya çıkan sonuçlara göre ilçe belediyesince sunulan hizmetlerin kalitesi ve verimliliği belde belediyesinden daha iyi durumdadır. Bu kapsamda hizmette etkinlik ve verimlilik açısından belde belediyesinin kapatılmasının yerinde bir karar olduğu söylenebilir. Temsil sorunsalına ilişkin olarak belde belediyesi ile ilçe belediyesi arasında çok büyük değişiklikler olmadığı görülmektedir. Bu anlamda temsile ilişkin çok büyük sorunlar olmadığı, hatta gelişen teknoloji ile birlikte yeni iletişim olanaklarının belde halkı tarafından kullanılarak ilçe belediyesine ulaşıldığı görülmektedir." denilmiştir (Belli ve Aydın, 2016: 1712).

Açık bir şekilde görülmektedir ki, kamu hizmetleri ve özellikle yerel hizmetlerin sunumunda etkinlik ve verimlilik vazgeçilmez ilkelerin başında gelmektedir. Tarihsel süreçte sayısız deneme yanılmalarla birlikte onlarca tecrübe biriktirmiş insanlığın bundan sonrada hizmet sunumunda bu iki ilkeyi geliştirerek sürdüreceği ortadadır.

\section{Köy, Mahalle ve 6360 Sayılı Kanun}

Yerinden yönetim ilkesinin uygulandığı yerel yönetimler, kamu tüzel kişiliğine sahip kuruluşlar olarak, merkezi yönetimin hiyerarşisi dışında ve ona karşı belirli ölçülerde bağımsız birimlerdir (Toprak, 2014: 33). Yerinden yönetim merkezi yönetimle birlikte yürütme organını meydana getirir. Yerinden yönetimde, görev, yetki ve sorumluluklar, personel ve mali kaynaklar, coğrafi ölçüt ya da hizmetin niteliğine göre merkezden ayrı özerk bir şekilde kullanılmaktadır. Ülkeler merkezi yönetim ile yerinden yönetimin kazandığı ă̆ırlığa göre merkeziyetçi ya da âdem-i merkeziyetçi olarak nitelendirilebilirler (Parlak ve Ökmen, 2015: 6). Yerinden yönetim kuruluşlarını "yer yönünden yerinden yönetim kuruluşları", "hizmet yönünden yerinden yönetim kuruluşları" ve "kamu kurumu niteliğindeki meslek kuruluşları" olmak üzere üç yönetim yapısı bağlamında incelemek mümkündür (Parlak ve Ökmen, 2015: 7). Köy, kent, il düzeyindeki yerel ortak nitelikli kamu hizmetlerini yürütmek amacıyla oluşturulan yönetim kurumlarına "Mahalli İdareler" veya "Yerel Yönetimler" denilmektedir (Ulusoy ve Akdemir, 2001: 19). Bu iki kavram da aynı amaca hizmet etmekte, Türk yönetim sistemi içinde yer alan II Özel İdaresi, belediye ve köy yönetimlerini tanımlamaktadır (Demir ve Karakütük, 2003: 68). Bu çalışma kapsamında mahalleye dönüşen köylerin durumu değerlendirilmiştir.

Demokrasinin ve yerel kalkınmanın vazgeçilmez organizasyonları olan yerel yönetimlerin, yerel kamusal mal ve hizmetleri daha etkin, verimli, kaliteli ve sürekli bir şekilde temin edebilmesi, yine geleceğe yönelik stratejiler ile planlamalarını reel biçimde yapabilmesi, bu kuruluşların diğer kurum, kuruluş ve organizasyonlarla kuracakları ilişiklerin gücüne de bağııdır. Özellikle son dönemde siyasal alanda müzakereci ve oydaşmacı demokratik yaklaşımın yönetsel alandaki yansıması olan yönetişimci modelin Türkiye'de yerel yönetimler açısından hayata geçirilebilmesi; ancak bu kuruluşların yerel kamusal mal ve hizmetlerin sunumunda birlikteliklerinin güçlü bir şekilde kurumsallaşmasına bağlıdır (Eryiğit, 2016: 293). 


\subsection{Köy ve Köy Muhtarlığı}

Insanların bir arada ve topluca yaşama güdü ve ihtiyacının bir sonucu olarak kendiliğinden ortaya çıkmış en eski yerel yönetim birimi köydür. Osmanlı İmparatorluğu'nun ilk dönemlerinden son dönemlerine kadar bir şekilde varlığını koruyan ve Osmanlı'dan Türkiye Cumhuriyeti'ne devredilen yönetsel yapının bir parçası olan köyler, içinde bulundukları dönemlerin örf ve adetlerini temel alan kural ilişkileri içinde var olagelmişlerdir (Parlak ve Ökmen, 2015: 325). Anayasa'da belediye ve il özel idareleri ile birlikte yerel yönetim kuruluşu olarak sayılan köy, yerleşme alanı ve idari birim olmanın ötesinde, sosyolojik ve kültürel açıdan başta olmak üzere birçok yönden toplumu etkilemiştir.

Türkiye'de köy, nüfusu az, ekonomik yapısı büyük ölçüde tarıma dayalı, homojen, kendisine özgü toplumsal ilişkileri bulunan yerleşim birimleri olarak kullanılmaktadır (Toprak, 2014: 137). Benzer bir tanımlama yapan Keleş, köy için, yönetim durumu, toplumsal ve ekonomik özellikleri ya da nüfus yoğunluğu yönünden kentten ayırt edilen, genellikle tarımsal uğraşıda bulunmak gibi işlevlerle ayrımlaşan ve belirlenen, konutları ve öteki yapıları bu yaşamı yansıtan yerleşme birimi demektedir (Keleş, 1998: 93). Kavruk, köy için, Farsça kökenli bir kelime olduğunu ve "mahalle, semt, civar, etraf, sokak, yol tabirleri ile Türkçe'de meskûn yerlerin en küçüğüne verilmiş isim olduğunu söyler (Kavruk ve diğerleri, 2012: 9).

Kamu idarelerinin en küçüğü ve mahalli idarelerin en eskisi olan köyü, Kavruk, (Duran, 1982: 171)'den aktararak, cami mektep, otlak, yaylak, baltalık gibi orta malları bulunan, toplu veya dağınık evlerde oturan insanların, bağ bahçe ve tarlalarıyla birlikte meydana getirdikleri teşkilat birimi olarak ifade eder. Türkiye'de tarihi süreciyle ve kendiliğinden oluşmuş tek mahalli idare köydür. Köy, il ve belediye idarelerinden farklı olarak ve tüzelkişiliği olmamasına rağmen, Osmanlı döneminin başlangıcından itibaren başlı başına bir varlık olarak yaşamını sürdürmüştür. İslam hukukunda tüzelkişilik kavramı olmadığından köy, Cumhuriyet dönemine kadar çeşitli ve dağınık mevzuat hükümleriyle ve örf ve adet hukukuna göre yürütülegelmiş bir topluluktur (Kavruk, 2004: 16-17). Köy yerleşimleri günümüzde medeniyetin taşıyıcısı olarak görülen kentlerin ortaya çıkışına, nüfus ve alan olarak büyümesine önemli katkılar sağlamışlardır (Kavruk, 2012: 1). Gerçekten de, yönetim kültürümüzde en eski ve değiş̧imlerden, özellikle dışardan gelen etkilerden, en fazla korunmuş ender birimlerden birisi köydür. Günümüzde teknoloji başta olmak üzere yaşanan baş döndürücü gelişmelerle kentlerde erişilebilen imkânlara köylerde de erişilebilse de hala kendine has yapısını koruyan onlarca köy mevcuttur.

Köylere ilk kez tüzel kişiliğin tanındığı, 1924 yılında kabul edilen Köy Kanunu, köyler ile ilgili temel düzenlemeleri içermektedir. Köy kanununun bu gün artık en az uygulanabilen kısmı, kanunun köylü tarafından yapılmasını emrettiği kamu hizmetlerinin ifa edilmesi ile ilgili olan hükümleridir. Gerçekten köy kanunu köye içme suyu getirilmesi, pis suların tahliyesi için kanallar yapılması, bataklıklar ve su birikintilerinin kurutulması, köyün bir başından öbür başına kadar çaprazlama yol yapılması, köy meydanı açılması, köy odası ve köy misafir odası yapılması, mescit ve okul yapılması, köye korucu, sığırtmaç, danacı ve çoban tutulması gibi birçok mecburi hizmetlerin yanında mecburi olmayan hizmetlerin de ifa edilmesini köy halkının yerine getireceğini açıkça ifade etmesine rağmen günümüzde bu hizmetlerin yürütülmesi çok büyük oranda merkezi bütçenin imkânları kullanılarak gerçekleştirilmektedir (Uysal ve Mecek, 2015: 1171).

Köy yönetiminin organları, köy muhtarı, köy ihtiyar meclisi ve köy derneğidir. Köy yönetimi köyün bir yerel yönetimi birimi olması hasebiyle köyde bulunanların yerel ve müşterek nitelikteki ihtiyaçları karşılayacak hizmetleri sağlamakla görevlidirler. 442 Sayılı Kanunda, köy yönetiminin sağlamak durumun olduğu hizmetlere ilişkin olarak, 12. maddede görevler, "mecburi olan 
işler" ve "köylünün isteğine bağlı olan işler" olarak iki başlıkta tanımlanmış, 13. ve 14. maddelerde ayrıntılı olarak listelenmiştir. Buradaki görevlerin çoğunun günümüz köylerinde artık geçerliliğini yitirdiğini söylemek yanlış olmaz. Diğer taraftan, köye ilişkin mevzuatın, günümüz koşullarında köy gerçekleri dikkate alınarak ve mevcut mevzuat taranarak güncel hale getirilmesi gerektiği ortadadır.

Köy Kanununda mecburi ve isteğe bağı ılan işler liste halinde ayrı ayrı sıralanmıştır. Genel bir tanım yapılmayıp tek tek sıralanması kanunun yapıldığı döneme ilişkin ipuçları verecek nitelikte görülebilir.

442 Sayılı Köy Kanununda köy muhtarının göreceği işler devlet işleri ve köy işleri olmak üzere iki ayrı maddede sıralanmıştır. Köy işlerinin birçoğunun bütün köylü birleşerek imece ile yapılacağına yer veren maddesi bile başlı başına, köy yönetiminin işleyişini düzenleyen bu kanunun dünyada ender bir mevzuat olduğunu göstermektedir. Diğer taraftan, muhtarın hem devlet işleri ile hem de yerel hizmetler olan köy işlerini yapmakla görevlendirilmesi köy muhtarının konumu açısından oldukça dikkat çekicidir. Köyün kamu tüzel kişiliğini temsil etmesi, mahkemelerde davalı veya davacı olarak köyü temsil etmesi, köy ihtiyar meclisi kararlarını uygulaması, köy işlerine harcanacak paraları toplaması ve harcama yapması gibi görevleri yürütmesi karşılığı muhtarlara merkezi yönetim tarafından asgari ücretle eşit aylık bağlanmıştır. Yine sigorta primleri merkezi yönetim tarafından ödenmektedir.

Muhtarların bütün kararları kaymakam veya valinin vesayet denetimine tabidir. Kaymakam veya vali köyün faydasına olmayan kararlar bozabilmektedir. Fakat onun yerine karar verememekte, karar yine köylü ve seçtiği temsilciler tarafından verilmektedir. Yine görevini yapmayan muhtarlar il idare kurulunca görevden uzaklaştırılabilir (Parlak ve Ökmen, 2015: 334).

\subsection{Mahalle ve Mahalle Muhtarlı̆̆ı}

Mevzuatta olmasa da hayatın içinde, özellikle yerel hizmetler söz konusu olduğunda ilk akla gelen ölçek mahalledir. Merkezi ya da yerel, mahallenin hangisine konumlandırılacağı halen netlik kazanmadığı için, şimdilik "ikisinin ortasında, arada bir yer" olarak konumlandırabiliriz. Mahalle, Türk yönetim geleneği ve toplum hayatı açısından çok önemli bir kurumdur. Özellikle kentsel alanda ilişkileri tanımlayan, toplulukların kimliklerinin oluşmasında belirleyici olan ve kentteki toplumsal dokunun tanımlanmasında etkili bir alanı ifade eden mahalle, aynı zamanda hem merkezi yönetimin hem de yerel yönetimlerin hizmet sunumunda vazgeçilmez bir kurum olarak varlığını sürdürmektedir. Cumhuriyet tarihi boyunca mahalle yönetimi "mahalle muhtarlığı" çerçevesinde tanımlanmış ve daha çok merkezi yönetimin vatandaşa en yakın düzeydeki hizmetlerini kolaylaştırıcı bir yardımcı birim olarak görülmüştür. Bu nedenle, çok uzun zamandır kamu yönetimi sistemimizde var olan mahalle yönetimi bir yerel yönetim birimi olarak düzenlenmemiş ve doğrudan kent hizmetleri sunmasına ilişkin bir çabada bulunulmamıştır. Aksine, yönetim tarihimiz boyunca dönem dönem varlığına son verilmesi ve yönetim sisteminden tamamen çıkarılması yönünde girişimlerde bulunulmuştur. Türkiye'nin yakın dönemde yaşadığı yerelleşme süreci ve yerel yönetim reformları bu konuda yeni bir perspektifin kabul edildiğini göstermektedir (Ömürgönülşen ve Sadioğlu, 2014: 293-294).

Mahalle muhtarlığı için yürürlükte üç kanun bulunmaktadır. Bunlar; 1944 yılında çıkarılan 4541 Sayılı Şehir ve Kasabalarda Mahalle Muhtar ve İhtiyar Heyetleri Teşkiline Dair Kanun, 5393 Sayılı Belediye Kanunu ve 657 Sayılı Devlet Memurları Kanunu'dur. 5393 Sayılı Belediye Kanunu 9. maddesinde mahallenin muhtar ve ihtiyar heyeti tarafından yönetileceği hükmüne yer verir. 
Mahalle olma koşulunu 500 nüfusa bağlayan bu madde de muhtarın görevlerine; "muhtar, mahalle sakinlerinin gönüllü katılımıyla ortak ihtiyaçları belirlemek, mahallenin yaşam kalitesini geliştirmek, belediye ve diğer kamu kurum ve kuruluşlarıyla ilişkilerini yürütmek, mahalle ile ilgili konularda görüş bildirmek, diğer kurumlarla iş birliği yapmak ve kanunlarla verilen diğer görevleri yapmakla yükümlüdür" diyerek yer verir. Aynı madde de, belediyenin, mahallenin ve muhtarlığın ihtiyaçlarının karşılanması ve sorunlarının çözümü için bütçe imkânları ölçüsünde gerekli ayni yardım ve desteği sağlayacağı, kararlarında mahallelinin ortak isteklerini göz önünde bulundurup, hizmetlerin mahallenin ihtiyaçlarına uygun biçimde yürütülmesini sağlamaya çalışacağını belirtir. Genel hatlarıyla belediye mahalle ilişkisinin yasal özeti görülebilecek bu maddenin belediye yönetimi üzerinde bağlayıcılığı her zaman tartışma konusu olacaktır.

Mahalle yönetimi özerkliği ve yasal dayanağı olan bir yönetim birimi olmadığı gibi merkezin bir kuruluşu da değildir (Bulut, 2001: 34). Ancak, şehir ve Kasabalardaki Mahalle Muhtar ve îhtiyar Kurulları Tüzüğü’ne göre mahalle muhtarı ve ihtiyar kurullarına verilen görevlerde merkezi yönetime yönelik işlerin fazlalığı dikkat çekicidir. Bu görevlerden bazılarının geçerliliği her geçen gün kaybettiğini söylemek mümkündür. Mahalle muhtarına, kendisine çalışma yeri olarak belli bir yer ayırmak ve gündelik işlerini burada görmeğe yetecek kadar günün belli saatlerinde ilgili yerde bulunmak, söz konusu yerde hangi saatlerde olacağını mahalle halkına ilan etmek ve yerin en büyük mülki amirine bildirmek, giriş kapısının uygun bir yerine muhtarlığın başlığını taşıyan bir levha koymak tüzükte yer verilen görevler arasındadır.

Mahalle muhtarlarının görevleriyle ilgili herhangi bir suçtan dolayı soruşturulması usulünde yetkili makam mahallin en büyük mülki amiridir. Mahalle muhtarı ve ihtiyar heyeti üyeleri görevlerini geciktirir veya ihmal ederse ilç̧e İdare Kurulu tarafından görevlerine son verilir.

\subsection{Sayılı Kanun ile Yapılan Değişiklikler}

6360 Sayılı Kanun ile 16 binden fazla köy muhtarlığı mahalle muhtarlığına dönüştürülmüştür. Diğer bir ifade ile köylerin yüzde 47'sine yakınının tüzel kişiliği kaldırılarak mahalleye dönüştürülmüştür (Koçak, 2015: 1317). Köy muhtarlığı döneminde köyün ihtiyacı olan hizmetleri tamamlayamamış mahallelerin yeni muhatabı ilçe belediyeleri ve büyükşehir belediyesi olmuştur. Diğer taraftan, geleneksel yönetim birimi olan köyün kaldırılmış olması tarihsel süreçte oluşmuş geleneksel değerlerin ve çözüm mekanizmalarının da geçersiz hale gelmesine sebep olacaktır. Koçak, bu duruma; "köy halkının söz konusu gelenekler ışığında muhtardan ve ihtiyar heyetinden bazı beklentileri söz konusudur. Köyler mahalleye dönüştükten sonra muhtarın yetkilerinin kısıtlanmış olması ve ilçe belediyelerinin köyler üzerinde bir takım tasarruf hakkına sahip olmaları bazı yeni problemlerin doğmasına neden olabilecektir" ifadeleriyle dikkat çekmektedir (Koçak, 2015: 1317). Köylerin mahalleye dönüştürülmesiyle mahallelerin rolünün yeni bir boyut kazandığını söyleyen Oktay ve diğerleri, asıl önemli tartışmanın köylerin dinamizminin mahalle içinde nasıl soğurulacağının olduğunu söylemektedir. Mahallelerin ikincil ya da vasıfsız bir birim olduğunu imadan çok dinamizm farklılıklarına işaret eden, mevcut altyapı, hukuki düzenlemeler ve toplumsal beklentiler ile köylerin mahalleler içinde nasıl yer bulacağı tartışmalara açıktır (Oktay ve diğerleri, 2014: 368).

6360 Sayılı Kanun ile büyükşehir sınırları içerisindeki belde belediyeleri ile köylerin mahalle statüsüne dönüştürülmesi sonucunda, kentsel alanın dışındaki kırsal alanlarda da varlık kazanmıştır. Böylece, daha fazla olan köy sayısı ile daha az olan mahalle sayısı yer değiştirmiştir. Mevcut yapı, görev, yetki ve sorumluluklarında herhangi bir değişiklik yapılmaksızın mahalleye fiilen yeni bir tür (kırsal mahalle) eklenmiş ve bir süre daha (en azından yeni bir yerel reforma kadar) 
varlığını sürdürme imkânı tanınmıştır. Aslında ilk defa 2005 tarih ve 5216 sayılı Büyükşehir Belediyesi Kanunu'nun Geçici 2. maddesi yoluyla ortaya çıkan bu yeni türü ifade eden kırsal mahallenin ne derecede işlevsel olacağını ise zaman gösterecektir (Bilgin, 2013: 290).

6360 Sayılı Kanun ile köyden mahalleye dönüşen yerlerde muhtarların yaptığı işlere ilişkin oluşan değişiklikler, Acar ve Koç tarafından Muğla ili Fethiye ilçesinde yapılan bir çalışma sonrasında listelenmiştir. Değişiklikler Tablo 1'de sunulmuştur (Acar ve Koç, 2016: 189).

Tablo 1: 6360 Öncesi ve Sonrası Genel Olarak Muhtarların Yaptığı Işler

\begin{tabular}{|c|c|c|}
\hline Genel Olarak Yönetime Katılım ve Mali Açıdan Muhtarların Yaptığı İşler & $\begin{array}{l}6360 \\
\text { Öncesi }\end{array}$ & 6360 \\
\hline Köy /belde adına karar alabilme & Var & Yok \\
\hline Bütçe Yapma & Var & Yok \\
\hline İhtiyar meclisi kararı ile köy işlerine harcanacak parayı toplamak & Var & Yok \\
\hline Köy işlerine harcanacak parayı topladıktan sonra harcamak için emir vermek & Var & Yok \\
\hline $\begin{array}{l}\text { Bir ay içinde nerelere ve ne kadar para harcamış ise gelecek ay başında hesaba- } \\
\text { tını ihtiyar meclisine vermek; }\end{array}$ & Var & Yok \\
\hline $\begin{array}{l}\text { Köy işlerinde hem davacı, hem hasım olarak mahkemede bulunmak ve isterse } \\
\text { mahkemeye diğer birini yerine (vekil) gönderme. }\end{array}$ & Var & Yok \\
\hline İhtiyar meclisi ile görüştükten sonra köylüyü işe çağırmak & Var & Yok \\
\hline Su Faturası, Sulama Organizasyonu & Var & Yok \\
\hline Posta Tebligat İşlemleri & Var & Var \\
\hline Güvenlik kuvvetlerine yardım & Var & Var \\
\hline Askerlik işlemleri & Var & Zayıf \\
\hline Nüfus Müdürlüğü işlemleri & Var & Var \\
\hline Seçmen Listesi vb. İşlemler & Var & Var \\
\hline TEDAŞ (Elektrik aboneliği vs.) & Var & Zayıf \\
\hline
\end{tabular}
Kaynak: Acar ve Koç, 2016: 189.

2012 yılı sonrasında büyükşehir belediyeleriyle ilgili gelişmelerin, yeni büyükşehir modeli içerisinde mahalle muhtarlıklarının sorunlarının çözülebileceği yönünde bir beklenti oluştursa da kapsamlı ve başarılı bir düzenleme yapılamadığını söyleyen Ömürgönülşen ve Sadioğlu, mevcut büyükşehir modelinin zaten sorunlu olan mahalle yönetimi esas alınarak oluşturulduğu için pek çok eski ve yeni soruna gebe olarak doğduğunu belirtmektedir. Bu sorunlara örnek olarak, büyükşehir belediyesi ve ilçe merkezlerinin uzağında çok nüfuslu ama yetkisiz ve kaynaksız kırsal mahalleler oluşturulması, belde belediyeleri ve köylerin kapatılmasının yerel özerklik karşısındaki durumu, taşınmaz malların devri, tanınan vergi ve benzeri muafiyetlerin birkaç yıl sonra sona erecek olması, mahalle muhtarlıklarının mali kaynak, idari yetki, ofis ve benzeri sorunlarını göstermektedir (Ömürgönülşen ve Sadioğlu, 2014: 300).

Öztop, 6360 Sayılı Kanun sonrası mahalle muhtarlıklarının kurumsal yapılanma ihtiyacı olduğuna dikkat çekmekte ve mahalle nüfusuna göre belirli sayıda çalışan desteği verilmesi gerektiğini söylemektedir. Yine, il ve ilçelerde mahalle muhtarlıklarının sayısının ve sınırlarının ye- 
niden belirlenmesine ihtiyaç olduğunu belirtmekte ve özellikle kent merkezlerindeki muhtarlıkların optimum büyüklüğe göre planlanması gerektiğini vurgulamaktadır (Öztop, 2017: 33). Mevcut mahalleler ile köyden mahalleye dönüşen yerlerin ihtiyaçlarının farklı olmasından hareketle muhtarlıkların kentsel ve kırsal olarak ayrılması, en azından geçiş döneminde bu durumun ayrıcalıklı olarak dikkate alınması gereklidir (Öztop, 2017: 34). Gerek tarihsel değeri, gerekse ülkemizin mevcut koşulları mahalleyi ve muhtarlığı yapılacak düzenlemelerin temelinde konumlandırmaktadır. Halkın yönetime katılımının arttırılması, hizmetlerin etkili ve verimli bir şekilde sağlanması, yerinden yönetimin günümüz koşullarında en üst seviyede gerçekleştirilebilmesi için muhtarlığın, büyükşehir/bütünşehir gelişim süreci ile birlikte sahadaki etkileri dikkate alınarak, yeniden yapılandırılması gerekmektedir (Demirkaya ve Koç, 2017: 146).

\section{Araştırma Evreni, Kapsamı ve Yöntemi}

Mahalleye dönüşen köylerin muhtarlarının hizmetlerde etkinlik ve verimliliğe ilişkin algısını araştırmak amacıyla yapılan bu çalışmada anket tekniği tercih edilmiştir. Ankette yer alan soruların hazırlanmasında kaynakçada yer alan teorik ve uygulamalı çalışmalar ile birlikte, Muğla özelinde yapılan saha araştırmalarından yararlanılmıştır. Çalışma kapsamında yerel hizmetlerde etkinlik ve verimliliğin ne ölçüde sağlanabildiğinin ortaya konması amaçlanmıştır. Bilindiği gibi kamu hizmetlerinin kaliteli, etkin ve verimli bir şekilde karşılanması 6360 Sayılı Kanun ile getirilen dönüşümün ana hedeflerinden birisi olmuştur. Köyden mahalleye dönüşen yerlerde yerel hizmetlerin sunumunda en önemli aracı konumunda bulunan muhtarların etkinlik ve verimlili-

ğin yeterli düzeyde sağlanıp sağlanmadığına ilişkin algılarını ortaya çıkarmak amacıyla sorular yapılandırılmıştır.

Çalışmanın evreni; Muğla ilinde 6360 Sayılı Kanuna göre köyden mahalleye dönüştürülen yerlerde, dönüşüm öncesi köy muhtarı olup, halen ilçeye bağlı mahalle muhtarı olarak göreve devam eden muhtarlardır. Araştırmanın hedefleri doğrultusunda yargısal (iradi) örnekleme yapılmıştır. Söz konusu evrende muhtarlara araştırmacı tarafından birebir ulaşılarak anket soruları yönlendirilerek araştırma gerçekleştirilmiştir.

Araştırma; Muğla'nın ilçeleri genel özelliklerine göre (turizm, tarım, ticaret ve sanayi ağırlıklı olmaları) kategorilendirilerek 8 ilçede uygulanmıştır. İlçelerin öne çıkan özellikleri dikkate alınmıştır. Benzer özelliği fazla olan ilçelerden sadece birisi araştırmaya dâhil edilmiştir. Örneklem olarak seçilen 8 ilçede, (Bodrum, Dalaman, Fethiye, Köyceğiz, Kavaklıdere, Menteşe, Seydikemer ve Yatağan) 218 köy mahalleye dönüşmüştür. 2018 mahallede, 6360 Sayılı Kanun çıkmadan önce köy muhtarı olup, 2014 Yılı Mahalli İdareler seçimleri sonunda tekrar seçilen muhtar sayısı 117'dir. Köy tüzel kişiliği var iken muhtarlık yapmış ve tekrar seçilerek 3 yıldır mahalle muhtarlığını sürdüren 81 mahallenin muhtarı ile araştırmacı tarafından birebir görüşülmüştür. Muhtarlara, kaygılardan ve dış unsurlardan etkilenmeyi en aza indirmek amacıyla, çalışmanın herhangi bir belediye ya da merkezi yönetim birimi çalışması olmadığı özellikle izah edilmiş ve akademik bir çalışma olduğu vurgulanmıştır. Görüşülecek muhtarların onayı alındıktan sonra görüşmeye başlanmıştır. Daha sonra elde edilen veriler Excel programında analiz edilerek çaıışma tamamlanmıştır. 


\subsection{Araştırma Bulguları}

6360 Sayılı Kanunun gerekçelerinden birisi olan hizmetlerde verimlilik ve etkinliğin ne ölçüde sağlandığı, beklentilerin gerçekleşip gerçekleşmediği, muhtarların gözüyle ortaya çıkarılmaya çalışıımış ve yeni durumda yerel hizmetlerin sağlanmasına ilişkin sorular yöneltilmiştir. Yerel hizmetlere ilişkin olarak, muhtarlara "6360 Sayılı Kanun ile birlikte hizmet alanının artması ve il sınırına genişlemeden dolayı yeterli hizmet almakta zorlanıyoruz" ifadesine katılıp katılmadıkları sorulmuştur. Bu soruya; "hiç katılmıyorum, katılmıyorum, kararsızım, katılıyorum ve tamamen katılıyorum" seçeneklerinden biri ile cevap vermeleri istenmiştir. Muhtarların görüşlerinden oluşan veriler Tablo 2' de sunulmuştur.

Tablo 2: Muhtarların Yeterli Hizmet Alınıp/Alınmadığına Iliş̧kin Görüşleri

\begin{tabular}{|c|c|c|c|c|c|}
\hline ilcçeler & Hiç Katılmıyorum & Katılmıyorum & Kararsızım & Katılıyorum & $\begin{array}{c}\text { Tamamen Ka- } \\
\text { tılıyorum }\end{array}$ \\
\hline Bodrum & 0 & 33 & 0 & 67 & 0 \\
\hline Dalaman & 0 & 33 & 0 & 67 & 0 \\
\hline Fethiye & 9 & 37 & 27 & 27 & 0 \\
\hline Kavaklıdere & 0 & 100 & 0 & 0 & 0 \\
\hline Köyceğiz & 0 & 49 & 17 & 17 & 17 \\
\hline Menteşe & 0 & 19 & 19 & 62 & 0 \\
\hline Seydikemer & 13 & 34 & 13 & 40 & 0 \\
\hline Yatağan & 0 & 38 & 8 & 54 & 0 \\
\hline Toplam & 4 & 35 & 12 & 48 & 1 \\
\hline
\end{tabular}

Not: Rakamlar \% olarak verilmiştir.

Bodrum ve Dalaman ilçelerinde muhtarların \% 67'si bu ifadeye katıldığını belirtmiştir. Her iki ilçede de "kararsızım" diyen muhtar olmaz iken, katılmadığını söyleyen muhtarların oranı \% 33 çıkmıştır. Bodrum ilçesinde muhtarların aldıkları hizmetleri yeterli görmediklerini söylemek yerinde olacaktır. Muhtarların bazıları Muğla'nın çok geniş alanı nedeniyle zaten yeterli hizmet beklentisi içine girmediklerini ifade etmişlerdir. Fethiye ilçesinde ifadeye katılanların oranı \% 27 ile diğer ilçelere göre düşük çıkmıştır. Kararsızım diyenlerin oranı \% 27, bu ifadeye katılmıyorum diyenlerin oranı \% 46 olmuştur. Diğer ilçelere göre Fethiye ilçesinde muhtarların yarıya yakınının hizmetleri yeterli gördükleri söylenebilir. Kavaklıdere ilçesinde görüşülen muhtarlar mahallelerinin yeterli hizmeti aldığını belirterek ifadeye katılmadıklarını belirtmişlerdir. Köyceğiz ilçesinde \% 34'ü katıldığını söylemiş, \% 17'si kararsız olduğunu ifade etmiştir. Katılmadığını söyleyen muhtarların oranı ise Fethiye'ye yakın oranda \% 49 çıkmıştır. Merkezde bulunan ilçe Menteşe'de de Bodrum ve Dalaman gibi ifadeye katılanların oranı yüksek çıkmıştır. \% 62 katılıyorum derken, \% 19 kararsız ve \% 19 katılmıyorum demiştir. Yatağan ilçesinde \% 54 katılıyorum derken, \% 38 katılmadığını ve \% 8 kararsız olduğunu ifade etmiştir.

6360 Sayılı Kanun ile birlikte hizmet alanının artması ve il sınıına genişlemeden dolayı yeterli hizmet almakta zorlandıklarını belirten muhtarların oranı genel toplamda \% 49 olurken, \% 12 kararsız olduğunu söylemiştir. \% 39 oranında ise muhtarlar yeterli hizmeti almakta zorlanmadıklarını ifade etmişlerdir. 
Muhtarlara "6360 Sayılı Kanun ile birlikte hizmet alanının artması ve il sınırına genişlemeden dolayı talepte bulunduğumuz hizmeti zamanında alamıyoruz" ifadesine katılıp katılmadıkları sorulmuştur. Bu soruya; "hiç katılmıyorum, katılmıyorum, kararsızım, katılıyorum ve tamamen katılıyorum" seçeneklerinden biri ile cevap vermeleri istenmiştir. . Muhtarların görüşlerinden oluşan veriler Tablo 3'de sunulmuştur. Bodrum ve Dalaman ilçelerinde bu soruya verilen cevaplar bir önceki soruya verilen cevaplar ile benzerlik taşımaktadır. Muhtarların bazılar yaptıkları talebin üzerinden çok zaman geçtikten sonra kendilerine ulaşıldığını ya da hizmetin sağlandığını belirtmişlerdir. İfadeye katılıyorum diyenlerin oranı \% 67, katılmıyorum diyenlerin oranı \% 33 çıkmıştır. Fethiye ilçesinde bir önceki soruya göre katılmıyorum diyenlerin oranı azalmıştır. \% 46 verilen ifadeye katıldığını belirtmiş, \% 27 kararsız olduğunu, \% 27'de ifadeye katılmadığını belirtmiştir. Kavaklıdere ilçesinde bir önceki soruda olduğu gibi muhtarlar zamanında hizmet aldıklarını ve ifadeye katılmadıklarını söylemişlerdir. Köyceğiz ilçesinde bu ifadeye katılanların oranı \% 50 çıkmış ve bu \% 50'nin \% 17'sini "tamamen katılıyorum” tercihi oluşturmuştur. Diğer ilçelerde "hiç katılmıyorum" ve "tamamen katılıyorum" tercihleri yapılmamıştır. Menteşe ilçesinde bir önceki soru ile benzer sonuçlar çıkmıştır. \% 62 talepte bulunduğu hizmeti zamanında alamadığını söylemiştir. \% 19 kararsız, \%19 aldığını belirtmiştir. Seydikemer ilçesinde bir önceki sorudan farklı sonuçlar çıkmıştır. Muhtarların \% 47'si ifadeye katıldıklarını ve zamanında talepte bulundukları hizmeti alamadıklarını söylemişlerdir. \% 13 kararsız olduğunu söylerken olumlu cevap verenlerin oranı Kavaklıdere ve Köyceğiz'den sonra en yüksek çıkan oran olan \% 40 çıkmıştır. Yatağan ilçesinde \% 54 ifadeye katıldığını belirtmiş, \% 11 kararsız olduğunu \% 35'de katılmadığını söylemiştir.

Bu ifadeye Muğla genelinde ise katılanların oranı \% 54, kararsızların oranı \% 11 ve katılmıyorum diyenlerin oranı \% 35 çıkmıştır. Bir önceki soruda \% 39 olan oranın \% 35’e düşmesi hizmeti aldığını söyleyenlerden bazılarının zamanında alamadığını belirtmesi sonucu olduğu söylenebilir.

Tablo 3: Muhtarların Zamanında Hizmet Alınıp/Alınmadığına ilişkin Görüşleri

\begin{tabular}{|c|c|c|c|c|c|}
\hline İlçeler & $\begin{array}{c}\text { Hiç } \\
\text { Katılmıyorum }\end{array}$ & Katılmıyorum & Kararsızım & Katılıyorum & $\begin{array}{c}\text { Tamamen Ka- } \\
\text { tılıyorum }\end{array}$ \\
\hline Bodrum & 0 & 33 & 0 & 67 & 0 \\
\hline Dalaman & 0 & 33 & 0 & 67 & 0 \\
\hline Fethiye & 9 & 27 & 27 & 46 & 0 \\
\hline Kavaklıdere & 0 & 100 & 0 & 0 & 0 \\
\hline Köyceğiz & 0 & 50 & 0 & 33 & 17 \\
\hline Menteşe & 0 & 19 & 19 & 62 & 0 \\
\hline Seydikemer & 0 & 40 & 13 & 47 & 0 \\
\hline Yatağan & 0 & 38 & 8 & 54 & 0 \\
\hline Toplam & 0 & 35 & 11 & 53 & 1 \\
\hline
\end{tabular}

Not: Rakamlar \% olarak verilmiştir.

Muhtarların kaynakların israf edilmeden tek elden yapılıp yapılmadığına ilişkin görüşleri alınmıştır. Bu amaçla muhtarlara; “6360 Sayılı Kanun öncesi her köy kendi işini (su, yol, ulaşım vb.) kendi yapmaya çalışırken şimdi tek elden kaynak israfı olmadan, verimli bir şekilde yapılıyor" ifadesine katılıp katılmadıkları sorulmuştur. "Hiç katılmıyorum, katılmıyorum, kararsızım, katılıyorum ve tamamen katılıyorum" seçeneklerinden biri ile cevap vermeleri istenmiştir. Çıkan veriler Tablo 4'de sunulmuştur. 
Tablo 4: Muhtarların Verimliliğe Iliş̧kin Görüşleri

\begin{tabular}{cccccc}
\hline ilç̧eler & Hiç Katılmıyorum & Katılmıyorum & Kararsızım & Katılıyorum & $\begin{array}{c}\text { Tamamen Ka- } \\
\text { tllıyorum }\end{array}$ \\
\hline \hline Bodrum & 0 & 50 & 17 & 33 & 0 \\
Dalaman & 17 & 17 & 0 & 49 & 17 \\
Fethiye & 0 & 18 & 18 & 55 & 9 \\
Kavaklıdere & 0 & 0 & 0 & 100 & 0 \\
Köyceğiz & 0 & 50 & 0 & 50 & 0 \\
Menteşe & 0 & 62 & 13 & 19 & 6 \\
Seydikemer & 0 & 40 & 7 & 53 & 0 \\
Yatağan & 0 & 23 & 15 & 54 & 0 \\
Toplam & 3 & 38 & 11 & 44 & 4 \\
\hline Not: Rakamlar \% olarak verilmiștir. & & & &
\end{tabular}

Bodrum ilçesinde muhtarların 6360 sayılı Kanun ile birlikte hizmetlerin tek elden kaynak israfı olmadan verimli bir şekilde yapıldığı ifadesine katılan muhtarların oranı \% 33 çıkmıştır. \% 17 kararsızım derken \% 50'si bu ifadeye katılmadığını söylemiştir. Dalaman ilçesinde bu ifadeye katılanların oranı \% 66 ile Kavaklıdere'den sonra en yüksek ilçe oranı olmuştur. Muhtarlar özellikle içme suyu konusunda, Muğla Büyükşehir Belediyesine bağlı MUSKi'den memnuniyetlerini dile getirmiştir. Dalaman'da kararsız olduğunu söyleyenler \% 17, katılmıyorum diyenlerin oranı da \% 17 olmuştur. Fethiye ilçesi ifadeye katıldığını söyleyen muhtarların \% 64 oranı ile yüksek çıkan ilçelerden birisi olmuştur. "Kararsızım" diyen muhtarların oranı \% 18, katılmıyorum diyen muhtarların oranı da \% 18 çıkmıştır. Kavaklıdere'de görüşülen muhtarlar bu ifadeye katıldıklarını söylemişlerdir. Köyceğiz ilçesinde \%50 ifadeye katıldığını belirten muhtarlar ve \% 50 katılmadığını söyleyen muhtarlar olmuştur. Menteşe ilçesi, "6360 Sayılı Kanun öncesi her köy kendi işini (su, yol, ulaşım vb.) kendi yapmaya çalışırken şimdi tek elden kaynak israfı olmadan, verimli bir şekilde yapılıyor" ifadesine katılanların oranı en düşük çıkan ilçedir. Muhtarların sadece \% 25'i katıldığını belirtmiştir. \% 13'ü kararsız olduğunu söylerken, \% 62'si bu ifadeye katılmadığını söylemiştir. Merkeze yakın mahallelerde bu sonuçların çıkması dikkat çekicidir. Seydikemer ilçesinde \% 53 ifadeye katıldığını söylemiş, \% 7 kararsız olduğunu ve \% 40’da katılmadığını belirtmiştir. Yatağan ilçesinde \% 54 katıldığını söylerken, \% 15 kararsız olduğunu söylemiştir. Yatağan'da muhtarların \% 31'i kaynak israfı olmadan verimli bir şekilde hizmetlerin sağlandığı görüşüne katılmadıklarını belirtmiştir.

Muğla genelinde ise \% 48 ifadeye katıldığını söylemiş ve bu oranın \% 4'ünü “tamamen katılıyorum" diyenler oluşturmuştur. Kararsızlar \% 11 çıkarken, ifadeye katılmadığını söyleyenlerin oranı \% 41 olmuştur. Muğla genelinde muhtarlar tarafından söylenen "6360 Sayılı Kanunun yararı en çok içme suyu konusunda olmuştur" ifadesi dikkat çeken önemli bir noktadır.

6360 Sayılı Kanun öncesi köy olan yeni mahallelerde muhtarların hemen hemen tamamı il Özel İdaresi ve Köylere Hizmet Götürme Birliğinden destek aldıklarını ifade etmişlerdir. Muhtarlara Muğla Büyükşehir Belediyesinin hizmeti eskiye göre daha iyi getirip getiremediği sorulmuştur. "6360 Sayılı Kanun öncesi il Özel İdaresi ve Köylere Hizmet Götürme Birliklerine göre büyükşehir belediyesi daha güçlü ve hizmeti daha hızlı getirebiliyor" ifadesine katılıp katılmadıkları sorulmuştur. Muhtarların nitel değerlendirmeler yanında bu ifadeye "Hiç katılmıyorum", 
"katılmıyorum", "kararsızım", "katılıyorum" ve "tamamen katılıyorum” seçeneklerinden biri ile cevap vermeleri istenmiştir. Veriler Tablo 5'de sunulmuştur.

Tablo 5: Muhtarların Yeni Durumda Önceye Göre Hizmetin Güçlü ve Hızlı Bir Şekilde Sağlanıp Sağlanmadığına illişkin Görüşleri

\begin{tabular}{cccccc}
\hline Illçeler & Hiç Katılmıyorum & Katılmıyorum & Kararsızım & Katılıyorum & $\begin{array}{c}\text { Tamamen Ka- } \\
\text { tilıyorum }\end{array}$ \\
\hline \hline Bodrum & 0 & 50 & 25 & 25 & 0 \\
Dalaman & 17 & 17 & 17 & 32 & 17 \\
Fethiye & 0 & 9 & 18 & 73 & 0 \\
Kavaklıdere & 0 & 0 & 0 & 50 & 50 \\
Köyceğiz & 0 & 50 & 0 & 50 & 0 \\
Menteşe & 0 & 62 & 13 & 19 & 6 \\
Seydikemer & 0 & 33 & 7 & 47 & 13 \\
Yatağan & 0 & 31 & 8 & 61 & 0 \\
Toplam & 1 & 38 & 13 & 42 & 6 \\
\hline
\end{tabular}

Not: Rakamlar \% olarak verilmiştir.

Muhtarlar, "6360 Sayılı Kanun öncesi il Özel İdaresi ve Köylere Hizmet Götürme Birliklerine göre büyükşehir belediyesi daha güçlü ve hizmeti daha hızlı getirebiliyor" ifadesine Bodrum ve Menteşe ilçelerinde \% 25 katıldıklarını belirtmişlerdir. Bu oran Dalaman ilçesinde \% 49 olmuştur. Bodrum'da "kararsızım" diyen muhtarların oranı \% 25, Menteşe'de \% 13 Dalaman'da ise \% 17 olmuştur. Bu ifadeye katılmadıklarını söyleyen muhtarların oranları bu üç ilçede; Bodrum'da \% 50, Menteşe'de \% 62 ve Dalaman'da \% 34 olarak çıkmıştır. Fethiye ilçesi ifadeye katılanların oranının en yüksek olduğu ilçedir. \% 73 bu ifadeye katıldığını belirtmiştir. Muhtarlar mahallelerinin yolları ve içme suyu konusunun bu görüşlerinde etkili olduğuna dikkat çekmişlerdir. Fethiye'de kararsız \% 18 ve ifadeye katılmayanların görüşü \% 9 olmuştur. Kavaklıdere'de görüşülen muhtarlar ifadeye katıldıklarını belirtmişlerdir. Bu ilçede oran \% 100'dür. Köyceğiz'de \% 50 oranında olumlu görüş belirtilirken kararsızım diyen olmamıştır. \% 50'de katılmadığını belirtmiştir. Seydikemer ilçesinde muhtarlar \% 60 oranında ifadeye katıldıklarını söylemiştir. \% 7 kararsızım derken \% 33 katılmadığını belirtmiştir. Yatağan ilçesi Seydikemer ile benzerlik göstermektedir. \% 61 ifadeye katıldığını söylemiştir. \% 8 kararsız kalırken \% 31 katılmadığını belirtmiştir.

Hizmetin eskiye göre daha güçlü ve hızlı geldiğini düşünen muhtarların Muğla genelindeki oranı \% 48 çıkmıştır. \% 13 kararsız olduğunu söylerken muhtarların \% 39'u büyükşehir belediyesinin eskiye göre daha güçlü ve hizmeti hızlı getirdiği görüşüne katılmadıklarını belirtmişlerdir.

\section{Değerlendirme ve Sonuç}

Dünyada yaşanan gelişmeler, her geçen gün çeşitlenen bilgi ve bu ikisindeki değişimden etkilenerek beklentileri her geçen gün farklııı gösteren insanların ihtiyaçları olan kamu hizmetlerini sunmakla görevli yerel yönetimlerin yapısı da doğal olarak değişmektedir. Hizmetlerde etkinlik ve verimlilik; son yıllarda yaşanan değişimlerin etkisiyle Türkiye'de çokça gündeme gelen kavramlardandır. Katılım ile birlikte kamu hizmetlerinde etkinliğin ve verimliliğin sağlanması ve beraberinde hizmetlerin mümkün olduğunca yerel boyutta sağlanması diğer öne çıkan ilkeler 
olmuştur. Türkiye'de demokrasinin güçlendirilmesi, yerel hizmetlerde kalitesinin artırılması amacıyla yapılan düzenlemelerde bu üç ilkeye vurgu sıkça yapılmaya başlanmış ve tavandan tabana hizmetler bu minvalde değerlendirilir hale gelmiştir.

2012 yılında, TBMM tarafından yasalaşma süreci tamamlanarak yürürlüğe giren 6360 Sayılı Kanunun getirdiği değişiklikler büyükşehir yönetimi yapılanması ve ilgili bileşenleri üzerine olmuştur. Önceki düzenlemelerin aksine radikal sayılabilecek bir tutum ile köklü yapısal değişiklikler gerçekleştirilmiştir. Neticede, büyükşehir belediyesi olan il sayısı otuza çıkmış, bu illerde il özel idareleri kaldııılmış, Yatırımları İzleme ve Koordinasyon başkanlıkları kurulmuş, belde belediyeleri ve köylerin tüzel kişiliği sonlandırılarak bağlı bulundukları ilçelerin mahallelerine dönüştürülmüştür. Yönetim geleneğimizde müstesna yeri bulunan köyler, yaşanan dönüşüm ile birlikte, sahip oldukları yönetim organları olan köy muhtarlı̆̆ını ve beraberinde tüzel kişilik kaynaklı haklarını kaybetmişlerdir. Daha önce köyde yetki ve sorumluluğu ile en başta gelen muhtarlar, köylerini henüz tanımayan ve artık önceki hizmetleri sağlamakla görevli ilçe ve büyükşehir belediyelerine talep ve sorunları ileten aracı konumuna düşmüşlerdir. Köyün adı, yeri, fiziki yapısı, doğal örtüsü ve nüfusu değişmemiş iken yönetsel niteliği değişmiş ve mahalle olmuştur.

Vatandaşların talep ve sorunlarının çözümünde yerel yönetim birimleriyle aracı konumda bulunan muhtarların, belediyelerin sorunların çözümünde ne ölçüde yardımcı olduklarına ilişkin algıları, 6360 Sayılı Kanunun 4 yıllık süreci açısından önemlidir. Muğla ölçeğinde, muhtarların yüksek sayılabilecek oranlarda hem ilçe hem de büyükşehir belediyelerinin yaklaşımlarına ilişkin olarak olumlu algı taşımaları kanunun hedefleri açısından olumlu sonuca örnek gösterilebilir. Bu noktada muhtarların bu olumlu algıyı destekleyecek örnekler vermeleri, muhtarların bu yönetimlere ilişkin olumsuz beyanda bulunamayacakları eleştirisini bertaraf edecek niteliği taşımaktadır.

6360 Sayılı Kanunun temel amaçlarından birisi de hizmetlerde etkinlik ve verimliliğin arttırılması belirlenmiş ve kanun bu amaca hizmet edecek şekilde yapılandırılmıştır. Muhtarların hizmet alanının il sınırına genişlemesiyle birlikte yeterli hizmetleri almakta zorlanıp zorlandıklarına ilişkin değerlendirmeleri sürece ilişkin bir fikir verebilecektir. Muğla ölçeğinde, ilçelerde farklı çıkmakla birlikte, genelde yarıya yakın bir oranda olumlu çıkması, dört yıllık bir deneyimin yaşandığı da göz önüne alınırsa olumlu olarak görmek mümkün olabilecektir. Aynı minvalde hizmetlerin zamanında alınmasına ilişkin değerlendirmede sonucun daha olumlu olduğu görülmektedir. Bu da geleceğe ilişkin olumlu beklentileri arttırmaktadır. Köy muhtarlığı döneminde her köyün kendi temel hizmetlerini kendi imkânları ile sağladığı, sağlayamadığı durumlarda il özel idaresi ya da KÖYDES vb. arayışlara girdiği muhtarların değerlendirmeleri yanı sıra literatüre de girmiş bir gerçektir. 6360 Sayılı Kanun ile birlikte bu tür hizmetlerin il ölçeğinde, tek elden verimli bir şekilde gerçekleştirilmesi hedeflenmiştir. Muğla'da muhtarların değerlendirmesi yarı olumlu yarı olumsuz çıkmıştır. Olumlu değerlendirmelerin merkezinde MUSKi tarafından içme suyu konusunda yapılan çalışmalar ile verimlilik sağlandığı algısı hâkimken, olumsuz değerlendirenlerin ise, ağırlıklı olarak, önceden KÖYDES aracılığıyla ya da kendi kişisel girişimleri ile merkezden hizmet alanlardan oluşması dikkat çekici bir ayrıntı olarak görülmektedir. Benzer bir değerlendirme de hizmetlerin daha güçlü ve hızlı getirilip getirilemediğine ilişkin istenmiş ve burada da oran yarıya yakın çıkmıştır. İkisi birlikte değerlendirildiğinde muhtarların gözüyle beklentilerin henüz karşılanamadığı söylenebilir.

6360 Sayılı Kanun, büyük şehirlerin yönetimine ilişkin köklü değişikler getiren, katılımcılık, hizmetlerde bütünlük, etkinlik ve verimlilik gibi ilkeleri amaçlamasıyla olumlu karşılanmış ancak 
kırsal alanları da kentsel alanların yönetimine dâhil etmesiyle çokça tartışılmış ve halen tartışılmaya devam eden bir kanun olarak dört yılı aşkın bir süredir uygulanmaktadır. Kırsal alanların kent merkezleri ile birlikte yönetilir hale gelmesiyle birlikte köy tüzel kişilikleri sonlandırılınca, dönüştükleri mahalle yönetimleri ön plana çıkmış ve zaten var olagelen sorunları ile birlikte, kırsal nitelikli yeni sorunlarla daha da büyüyerek çözüm bekleyen bir konuma gelmiştir. Sonuç olarak yerel hizmetlerin sunumunda ölçeğin önemi hizmetlerin zamanında ve yeterli olarak sunulmasında ortaya çıkmaktadır. Büyükşehir sınırları içinde ilçelerin özelliklerine göre hizmet beklentilerinin farklı olduğu görülmüştür. Aynı durum mahalleler için de geçerlidir. Bu farklılıklar muhtarların algılarını da etkilemektedir. Hizmetlerin etkin ve verimli şekilde sunulmasında bu çalışmada yer verilmeyen unsurlar da birlikte düşünüldüğünde, 6360 Sayılı Kanun ile birlikte, özellikle tüzel kişiliğinin kaldırılması sonrası icracı konumundan aracı durumuna düşen muhtarların belediyeler nezdinde etkinliklerinin arttırılması kırsal alanlara hizmet götürme sürecini olumlu etkileyecektir. Böylece kanun ile yetkileri ve mali güçleri arttırılan büyükşehir belediyelerinin kırsal alanlara ilişkin hizmetlerin planlanmasında ve yürütülmesinde kırsalın bakış açısı ve deneyimlerinden azami ölçüde faydalanma fırsatı doğmuş olacaktır. 


\section{Kaynaklar}

Acar Osman Kürşat ve Koç Mesut (2016). “6360 Sayılı Kanun İle Birlikte Mahalleye Dönüşen Belde Mahalle Muhtarlıkları ve Köy Muhtarlıklarının Yeni Durumu; Fethiye İlçesi Üzerinden Bir Değerlendirme”, Kaysem 10 Bildiriler Kitabı, İzmir, s.177-191.

Al, Hamza (2002). Bilgi Toplumu ve Kamu Yönetiminde Paradigma Değişimi, Ankara, Bilimadamı Yayınları.

Alkuş, Oktay (2015). “Kamu Yönetiminde Verimlilik: Aksaray il Müdürlüklerinde Bir Uygulama”, Kayfor 13 Bildiri Kitabı, Konya, 547-559.

Belli, Aziz, Aydın Abdullah (2016). “6360 Sayılı Yasa ile Kapatılan Belde Belediyelerinin Hizmette Etkinlik, Verimlilik ve Temsil Sorunsalı Üzerine Bir Alan Araştırması: Önsen Belediyesi Örneği”, Uluslararası Sosyal Araştırmalar Dergisi, Cilt:9, Sayı:43, 1698-1712.

Bilgin, Kamil Ufuk (2004). Kamu Performans Yönetimi Memur Hak ve Yükümlülüklerinin Performansa Etkisi, Ankara, TODAiE Yayını.

Bilgin, Kamil Ufuk vd. (2013). "Mevcut Durum ve Beklentiler Açısından Mahalle Yönetimi”, Kuramdan Uygulamaya Yerel Yönetimler ve Kentsel Politikalar, Editör: Yakup Bulut, Pegem Akademi, s.289-304.

Biricikoğlu, Hale ve Duyar, D. Duygu (2015). “6360 Sayılı Yasanın Genişleyen Büyükşehir Belediyesi Hizmet Sınırının Etkinlik Ve Verimliliğe Etkisi Bağlamında Değerlendirmesi: Sakarya Büyükşehir Belediyesi Örneği” Süleyman Demirel Üniversitesi Iktisadi ve Idari Bilimler Fakültesi Dergisi, Cilt: 20, Sayı:4, s.369-393.

Bulut, Yakup (1999). Büyük Şehir Yönetimine Kentsel Alt Örgütlenmelerin (STK, Mahalle...) Katılımı: Gaziantep Büyük Şehir Belediyesi Örneği, Yayınlanmamış Doktora Tezi, Marmara Üniversitesi, İstanbul.

Bulut, Yakup (2001). "Mahalle Muhtarlığı Üzerine Bir Araştırma”, Çağdaş Yerel Yönetimler, Cilt 10 Sayı 3, ss.32-51.

Ceritli, İsmail (2002). "Yerel Kent Hizmetlerinin Verimli Sunumu Açısından Uygun Kent Büyüklüğü ve Türkiye Örneği", Çağdaş Yerel Yönetimler Dergisi, Cilt:11, Sayı:2, Nisan, 7-24.

Demir, Hakan, Karakütük, Mehmet (2003). "Yerel Yönetimler ve Hizmette Yerellik: Subsidiarite İlkesi", Bilgi Sosyal Bilimler Dergisi, s. 65-77.

Demirkaya, Yüksel (2016). Türkiye'de Belediyeler için Performans Yönetimi Arayışı, Demirkaya, Y., (Ed.), Türkiye'de Yeni Kamu Yönetimi: Yerel Yönetim Reformu, İstanbul, WALD.

Demirkaya, Yüksel ve Koç Mesut (2017). “6360 Sayılı Kanun ile Birlikte Mahalleye Dönüşen Köylerde Değişimin Muhtarlığa Etkisi: Menteşe ve Seydikemer ilçeleri Üzerinden Bir Değerlendirme”, Strategic Public Management Journal, Cilt 3, Sayı 6, s.124-149.

Duben, Alan, Emrealp, Sadun (1993). Urban Management Development, İstanbul, IULA-EMME Publication.

Duran, Lütfi (1982). İdare Hukuku, İstanbul, Fakülteler Matbaası.

Drucker, Peter (1994). Management (Tasks, Responsibilities, Practices), Oxford, Butterworth-Heinemann Ltd.

Eryılmaz, Bilal (2012). Kamu Yönetimi, 5. Baskı, Kocaeli, Okutman Yayıncılık.

Eryiğit, Burak Hamza (2016). "Yerel Kalkınma Bağlamında Yerel Yönetim Birliklerinin Kuruluş Sürecinde Uygulanan Vesayet Denetimi ve Bir Model Önerisi", Marmara Üniversitesi Siyasal Bilimler Dergisi, Cilt 4, Sayı 1, s.283-295.

Göküş, Mehmet ve Alptürker, Hakan (2016). “6360 Sayılı Yasa ile Köy Yönetiminden Mahalle Yönetimine Geçiş Sonrası Etkin Hizmet Sunumuna Illişkin Muhtarların Görüşü: Silifke Köyleri Örneği”. Selçuk Üniversitesi Sosyal ve Teknik Araştırmalar Dergisi, Sayı: 11, s.67-86.

Kavruk, Hikmet (2004). Köy ve Mahalle: Yerleşim ve Yönetim Birimi, Ankara, Odak Yayınevi.

Kavruk Hikmet vd. (2012). Türkiye'de Köy Yerleşimi ve Yönetimi, Ankara, TODAiE.

Kaypak Şafak, Kara, Mehmet (2016). “6360 Sayılı Yasa ve Değişen Yerel Çevre Hizmetleri: Hatay'da Bir Uygulama”, Kaysem 10 Bildiriler Kitabı, İzmir, s.268-301.

Keleş, Ruşen. Kentbilim Terimleri Sözlüğü, Ankara, İmge Kitabevi.

Keleş, Ruşen (2012). Yerinden Yönetim ve Siyaset, İstanbul, Cem Yayınevi.

Kesgin, Bedrettin (2015). "Etkinlikle Verimlilik Arasında Belediyeler", Uluslararası Iktisadi ve Idari Incelemeler Dergisi, Sayı:14, s. 157-176.

Koçak, Yüksel (2015). “Mahalle Yönetiminin Kentsel Sorunların Giderilmesindeki Rolü ve Yeniden Yapılandırılması”, Kayfor 13 Bildiri Kitabı, Konya, s.1303-1325.

Kuyaksil, Ali (1994). "Yönetimin Verimliliği", Türk Idare Dergisi, 403, Ankara. 


\section{Eskişehir Osmangazi Üniversitesi IïBF Dergisi}

Negiz, Nilüfer (2017). Türkiye'de Büyükşehir Belediyelerde Hizmet Etkinliği ve Eğitim İlişkisi: Alan Araştırması ve Bir Model Önerisi, Süleyman Demirel Üniversitesi SBE, Doktora Tezi, Isparta.

Oktay, Ercan vd. (2014). "Köy Mahalleye Sığar mı? Köy ve Mahalleye İlişkin Bir Çözümleme”, Kayfor 12 Bildiriler Kitabı, Aydın, s. 355-370.

Ömürgönülşen, Uğur ve Uğur Sadioğlu (2014). “Mahalle Yönetiminin Dönüşümü ve Bütünşehir Modelinde Yeniden Yorumlanması", Kayfor 12 Bildiriler Kitabı, Aydın, 293-301.

Öner, Şerif (2006). Yeni Mevzuat Çerçevesinde Türkiye'de Belediye Yönetimi, Ankara, Nobel Yayınları.

Özden, Kemal (2014). Yerel Yönetimlerde Güncel Sorunlar ve Tartışmalar, Ankara, Seçkin Yayınevi.

Öztop, Sezai (2017). “Mülki İdare-Belediye İlişkileri”, Belediye Yönetimi ve Kamusal illişkiler, Editörler: Hamza Ateş, Mücahit Bıyıkoğlu, İstanbul, Der Yayınları.

Öztürk, Namık Kemal (2004). “Kamu Yönetiminde Verimlilik”, Türk Idare Dergisi, Eylül, 2004.

Parlak, Bekir, Ökmen, Mustafa (2015). Yerel Yönetimler, Bursa, Ekin Yayınevi.

Şahin, Elif Ayşe (2007). "Kamu Mali Karar Alma Süreçlerinin Etkinliği ve İç Denetim Fonksiyonu”, Süleyman Demirel Üniversitesi, Sosyal Bilimler Enstitüsü, Maliye Ana Bilim Dalı, Yüksek Lisans Tezi, Isparta.

Tortop, Nuri vd., (2007). Yönetim Bilimi, Ankara, Nobel Yayınları.

Toprak, Zerrin (2014). Yerel Yönetimler, Ankara, Siyasal Kitapevi.

Ulusoy, Ahmet ve Akdemir, Tekin (2001). Mahalli Idareler, Ankara, Seçkin Yayınevi.

Uysal, Yusuf ve Mehmet Mecek (2015). "Köylere Sunulan Kamu Hizmetlerinin Nitelik ve Niceliği: Kütahya İli Örneği”, Kayfor 13 Bildiri Kitabı, Konya, s.1169-1183.

Yıldırım, İbrahim (1984). "Bürokratik Örgütlerde İsrafla Sonuçlanan Yönetsel Bozukluklar", Yayınlanmamış Doktora Tezi, Atatürk Üniversitesi iiBF, Erzurum. 